\title{
Abundance and community structure of ammonia-oxidizing archaea and bacteria in an acid paddy soil
}

\author{
Xin Chen • Li-Mei Zhang • Ju-Pei Shen • \\ Wen-Xue Wei $\cdot$ Ji-Zheng He
}

Received: 6 November 2010 /Revised: 6 January 2011 / Accepted: 10 January 2011 /Published online: 20 January 2011

(C) Springer-Verlag 2011

\begin{abstract}
Nitrification is essential to the nitrogen cycle in paddy soils. However, it is still not clear which group of ammonia-oxidizing microorganisms plays more important roles in nitrification in the paddy soils. The changes in the abundance and composition of ammonia-oxidizing archaea (AOA) and ammonia-oxidizing bacteria (AOB) were investigated by real-time PCR, terminal restriction fragment length polymorphism, and clone library approaches in an acid red paddy soil subjected to long-term fertilization treatments, including treatment without fertilizers (CT); chemical fertilizer nitrogen $(\mathrm{N})$; $\mathrm{N}$ and potassium $(\mathrm{NK})$; $\mathrm{N}$ and phosphorus (NP); N, P, and K (NPK); and NPK plus recycled crop residues $(\mathrm{NPK}+\mathrm{C})$. The AOA population size in $\mathrm{NPK}+\mathrm{C}$ was higher than those in $\mathrm{CT}$, while minor changes in AOB population sizes were detected among the treatments. There were also some changes in AOA community composition responding to different fertilization treatments. Still few differences were detected in AOB community composition among the treatments. Phylogenetic analysis showed that the AOA sequences fell into two
\end{abstract}

\footnotetext{
X. Chen · L.-M. Zhang • J.-P. Shen · J.-Z. He $(\bowtie)$

State Key Laboratory of Urban and Regional Ecology,

Research Center for Eco-Environmental Sciences,

Chinese Academy of Sciences,

Beijing 100085, China

e-mail: jzhe@rcees.ac.cn

X. Chen

Graduate University, Chinese Academy of Sciences,

Beijing 100049, China

W.-X. Wei

Key Laboratory of Agro-ecological Processes in Subtropical

Region, Institute of Subtropical Agriculture,

Chinese Academy of Sciences,

Changsha 410125, China
}

main clusters: cluster A and cluster soil/sediment. The AOB composition in this paddy soil was dominated by Nitrosospira cluster 12 . These results suggested that the AOA were more sensitive than $\mathrm{AOB}$ to different fertilization treatments in the acid red paddy soil.

Keywords Nitrification · Ammonia-oxidizing archaea . Ammonia-oxidizing bacteria . Acid paddy soil . Fertilization · Real-time PCR · T-RFLP. Clone library

\section{Introduction}

Irrigated rice fields are subjected to temporal or permanent flooding during the rice growth. The paddy soils are predominantly anaerobic. However, a thin oxic layer is formed in the surface soil due to gradual diffusion through the flooding water (Conrad and Rothfuss 1991). In addition, microaerobic niches are also present in the field due to oxygen leakage from rice roots (Revsbech et al. 1999). Thus, aerobic nitrification can occur in the flooding paddy soils. Nitrification is essential to the $\mathrm{N}$ cycle in paddy soils. It couples with denitrification and has been suggested as a significant source of $\mathrm{N}$ loss in the paddy soils.

Nitrification is the microbial oxidation of ammonia, first to nitrite and subsequently to nitrate. Traditionally, the first step of nitrification is mainly carried out by ammoniaoxidizing bacteria (AOB). All known AOB occurring in soils belong to $\beta$-proteobacteria represented by the genera Nitrosospira and Nitrosomonas (Purkhold et al. 2000). For a long time, it was believed that only AOB possess the amo $A$ gene for ammonia monooxygenase, the key enzyme of ammonia oxidation (Rotthauwe et al. 1997). The occurrence of $\mathrm{AOB}$ has been investigated in the flooding 
paddy soils, including surface soil, rhizosphere, and bulk soil, based on the amoA gene (Briones et al. 2002; Nicolaisen et al. 2004; Bowatte et al. 2006, 2007; Chen et al. 2008; Wang et al. 2009; Chu et al. 2010; Fujii et al. 2010). Many studies indicate that Nitrosospira are predominant in the paddy soils (Bowatte et al. 2006; Chen et al. 2008; Chu et al. 2010) while Nitrosomonas are prevalent in high-N fertilizer paddy soils or in the surface of rice roots (Briones et al. 2002; Nicolaisen et al. 2004).

In the last few years, the traditional view of ammonia oxidation has been changed by the discovery of the amoA gene associated with the domain archaea (Venter et al. 2004; Könneke et al. 2005; Treusch et al. 2005), suggesting that ammonia-oxidizing archaea (AOA) may be another group of ammonia oxidizers. The AOA are widespread in marine and terrestrial environments with high abundance values (Francis et al. 2005; Leininger et al. 2006; Wuchter et al. 2006; He et al. 2007; Shen et al. 2008; Schauss et al. 2009). Several studies also indicated that AOA outnumbered AOB in paddy soils (Chen et al. 2008; Wang et al. 2009; Fujii et al. 2010), but the contribution of AOA to nitrification in the paddy soil is still unclear. Recently, some researchers found that archaea were not important for nitrification in their tested soils ( $\mathrm{Di}$ et al. 2009; Jia and Conrad 2009). However, other studies provided evidences for the important role of archaea in soil ammonia oxidation (Offre et al. 2009; Zhang et al. 2010). Especially, the AOA may be important actors within the $\mathrm{N}$ cycle in unfavorable environmental conditions, e.g., low nutrient availability, low $\mathrm{pH}$ or sulfide-containing environments (Valentine 2007; Erguder et al. 2009). It seems possible that the AOA could be an important player for nitrification in flooding acid paddy soils.

Some previous studies have shown that the abundance and community structure of ammonia-oxidizing microorganisms could change following different fertilization practices in upland soils (He et al. 2007; Shen et al. 2008). In this study, we hypothesized that long-term fertilization practices could result in the shifts of $\mathrm{AOB}$ and $\mathrm{AOA}$ population size and community structure in flooding acid paddy soils. Real-time PCR and terminal restriction fragment length polymorphism (T-RFLP) combined with clone library approaches based on amoA genes were used to characterize the abundance and community compositions of $\mathrm{AOA}$ and $\mathrm{AOB}$ in this study.

\section{Materials and methods}

Site description and soil sampling

The site was located at the Taoyuan Long-Term Experimental Station of Agro-ecosystem Observation, Chinese
Academy of Sciences $\left(28^{\circ} 55^{\prime} \mathrm{N}, 111^{\circ} 26^{\prime} \mathrm{E}\right)$, Hunan Province, China. It has a subtropical monsoon moist climate with a mean annual temperature of $16.5^{\circ} \mathrm{C}$ and precipitation of $1,447.9 \mathrm{~mm}$. The paddy soil was derived from quaternary red soil and classified as a waterlogged paddy soil. The fertilization experiments started in 1990 and received fertilizers every year since then, including six treatments with three replicates for each treatment in a random plot design. The treatments were control without fertilizer (CT); chemical fertilizer nitrogen $(\mathrm{N})$; $\mathrm{N}$ and potassium (NK); $\mathrm{N}$ and phosphorus (NP); N, P, and $\mathrm{K}$ (NPK); and NPK plus recycled crop residues $(\mathrm{NPK}+\mathrm{C})$. The annual input amounts of $\mathrm{N}, \mathrm{P}, \mathrm{K}$, and $\mathrm{C}$ were reported in a previous publication (Zheng et al. 2008). The rotation of early rice and late rice was employed, and the early rice season was from April to July and the late rice season from July to October. The soil was flooded during most periods of the rice growth. Top soil samples $(0-20 \mathrm{~cm})$ were collected from each replicate plot in May 2009 when the rice was in the tillering stage and the soil was waterlogged. Five soil cores (approx. $5 \mathrm{~cm}$ diameter) were taken from each plot and were mixed to form one composite sample. All samples were divided into two parts: one was stored at $4^{\circ} \mathrm{C}$ for chemical analysis and another stored at $-80^{\circ} \mathrm{C}$ for DNA extraction.

\section{Chemical analysis}

Soil $\mathrm{pH}$ was measured by a $\mathrm{pH}$ meter using a soil-to-water ratio of 1:2.5. Soil total $\mathrm{N}$ content was determined with an Elemental Analyzer (Vario EL III, Elementar, Germany). Soil ammonium and nitrate contents were extracted from fresh soil samples with $2 \mathrm{M} \mathrm{KCl}$ and determined by a Continuous Flow Analyser (SAN++, Skalar, Holland; Shen et al. 2008). Soil organic matter was measured using the $\mathrm{K}_{2} \mathrm{Cr}_{2} \mathrm{O}_{7}$ oxidation-reduction titration method. Particle size distribution was measured using the rapid sieving procedure of Kettler et al. (2001).

\section{Soil DNA extraction}

DNA was extracted from $0.5 \mathrm{~g}$ (fresh weight) paddy soil using MoBio UltraClean ${ }^{\mathrm{TM}}$ Soil DNA isolation kit (San Diego, CA, USA). The extracted DNA was checked on $1 \%$ agarose gel and the concentration was determined with Nanodrop ${ }^{\circledR}$ ND-1000 UV-vis spectrophotometry (USA).

Quantification of amoA gene by real-time PCR

Abundances of AOA and AOB were determined by realtime PCR using an iCycler iQ5 Thermocycler (Bio-Rad, USA) with the fluorescent dye SYBR-Green I. Amplification was performed in $25-\mu l$ reaction mixtures, including 
$12.5 \mu \mathrm{l} \mathrm{SYBR}{ }^{\circledR}$ Premix Ex Taq ${ }^{\mathrm{TM}}$ (Takara Biotechnology, Japan), $1 \mu$ l bovine serum albumin $\left(25 \mathrm{mg} \mathrm{ml}^{-1}\right), 0.5 \mu \mathrm{l}$ each primer $(10 \mu \mathrm{M})$ listed in Table 1 , and $2 \mu \mathrm{l}$ DNA template (1-10 ng), as described by Zhang et al. (2009). The standards and the DNA samples were performed on the same plate. The results were analyzed with the $\mathrm{iQ}^{\mathrm{TM}} 5$ software (Bio-Rad).

Terminal restriction fragment length polymorphism

For T-RFLP analysis, the PCR amplification was performed using primer pairs Arch-amoAF/Arch-amoAR and amoA1F/ amoA2R (Table 1), with each forward primer labeled with 6-carboxyfluorescein (FAM; Ying et al. 2010). PCR reactions $(50 \mu \mathrm{l})$ contained $5 \mu \mathrm{l} 10 \times$ PCR buffer $\left(\mathrm{Mg}^{2+}\right.$ plus $)$, $4 \mu \mathrm{l} 2.5 \mathrm{mM}$ dNTPs, $0.5 \mu \mathrm{l}$ Ex Taq HS polymerase (5U $\mu \mathrm{l}^{-1}$, Takara Biotechnology), $1 \mu \mathrm{l}$ of each primer, and $2 \mu \mathrm{l}$ DNA template (1-10 ng). A touchdown PCR strategy was employed for the amplification, consisting of an initial denaturation step at $95^{\circ} \mathrm{C}$ for $3 \mathrm{~min}$, ten cycles of $95^{\circ} \mathrm{C}$ for $30 \mathrm{~s}, 60^{\circ} \mathrm{C}$ (for $\mathrm{AOA}$ ) or $62^{\circ} \mathrm{C}$ (for $\mathrm{AOB}$, decreasing by $0.5^{\circ} \mathrm{C}$ per cycle) for $45 \mathrm{~s}, 72^{\circ} \mathrm{C}$ for $1 \mathrm{~min}$, followed by 30 cycles of $95^{\circ} \mathrm{C}$ for $30 \mathrm{~s}, 55^{\circ} \mathrm{C}$ (for AOA) or $57^{\circ} \mathrm{C}$ (for AOB) for $45 \mathrm{~s}, 72^{\circ} \mathrm{C}$ for $1 \mathrm{~min}$, and a final elongation step of $72^{\circ} \mathrm{C}$ for $10 \mathrm{~min}$. The labeled PCR products were gel-purified with the Wizard ${ }^{\circledR}$ SV Gel and PCR Clean-Up System (Promega, USA) and then digested with the restriction enzyme $M b o \mathrm{I}$ (Takara Biotechnology) at $37^{\circ} \mathrm{C}$ for $3 \mathrm{~h}$. The digestion products were precipitated with 0.1 volume of sodium acetate (3 M, pH 5.2) and 3 volumes of ice-cold ethanol at $-20^{\circ} \mathrm{C}$ overnight. After centrifugation at $16,000 \times g$ for $30 \mathrm{~min}$, the pellets were washed with $70 \%$ ice-cold ethanol and then air dried. The pellets were then dissolved in $10 \mu \mathrm{l}$ of sterile MilliQ water. The purified digestion products were mixed with deionized formamide and internal standard GeneScan ${ }^{\mathrm{TM}}-500$ LIZ (Applied Biosystems) at $95^{\circ} \mathrm{C}$ for 3 min and then determined with an ABI PRISM ${ }^{\circledR} 3130 \mathrm{XL}$ Genetic Analyzer (Applied Biosystems; Wang et al. 2009). The electropherograms were analyzed using Genescan analysis software v3.7 (Applied Biosystems). The relative abundance of the individual terminal restriction fragment (T-RF) was calculated as the percentage of total peak area in a given T-RFLP profile. Only those T-RFs with a relative abundance $>1 \%$ and fragment lengths in the range of $30-500 \mathrm{bp}$ were considered in the analyses.

\section{Cloning and sequence analysis}

To identify the T-RFs, three AOA clone libraries and three AOB clone libraries were constructed from CT, NK, and $\mathrm{NPK}+\mathrm{C}$ by the primer pairs Arch-amoAF/Arch-amoAR and amoA1F/amoA2R (Table 1) without FAM labeling. The PCR conditions, reaction mixtures, and purification were the same as T-RFLP analysis. The purified PCR products were ligated into the pGEM-T Easy Vector (Promega) and then transformed into Escherichia coli JM109 (Takara Biotechnology) according to the manufacturer's instructions. Random positive clones (about 40-60) were selected from these clone libraries and sequenced.

The obtained sequences were subjected to homology analysis with the software DNAMAN, version 6.0.3.48 (Lynnon Biosoft, USA). The sequences displaying more than $97 \%$ identity with each other were grouped into the same operational taxonomic units (OTUs). Only one representative sequence of each OTU was used for phylogenetic tree construction. The GenBank sequences most similar to representative sequences in this study and reference sequences for defining clusters were included in phylogenetic tree construction. Phylogenetic analysis was performed using MEGA, version 4.0, and the neighborjoining tree was constructed using $p$ distance with 1,000 replicates to produce bootstrap values (Tamura et al. 2007).

The sequences determined in this study have been deposited in GenBank nucleotide sequence database with accession numbers HQ215911-HQ215930.

\section{Statistical analysis}

The copy numbers of amoA gene were log-transformed prior to statistical analysis. Principle component analysis (PCA) was performed using CANOCO for Windows, version 4.5 , to determine the variation of T-RFLP profiles among the treatments. The relative abundances of T-RFs were directly used in PCA. The statistical analyses were performed using ANOVA and paired-sample $t$ test with SPSS for Windows. If significant differences were detected

Table 1 Primers used for molecular analyses

\begin{tabular}{lllll}
\hline Target group & Primer & Sequence(5'-3') & Length of amplicon (bp) & Reference \\
\hline AOB & amoA1F & GGGGTTTCTACTGGTGGT & 491 & Rotthauwe et al. (1997) \\
& amoA2R & CCCCTCKGSAAAGCCTTCTTC & & Francis et al. (2005) \\
AOA & Arch-amoAF & STAATGGTCTGGCTTAGACG & 635 & \\
& Arch-amoAR & GCGGCCATCCATCTGTATGT & & \\
\hline
\end{tabular}


$(P<0.05)$, the Student-Newman-Keuls test was used to check for quantitative differences between treatments.

\section{Results}

\section{Soil chemical properties}

There were some changes in soil $\mathrm{pH}$ values among the different fertilization treatments. The $\mathrm{pH}$ values in all treatments varied between 5.09 and 5.39 (Table 2). No significant differences in soil total $\mathrm{N}$ and organic matter were found among the treatments, except for $\mathrm{NPK}+\mathrm{C}$ which had significantly higher contents than the other treatments (Table 2). Soil $\mathrm{NH}_{4}^{+}-\mathrm{N}$ content in these treatments ranged from 27.08 to $85.91 \mathrm{mg} \mathrm{kg}^{-1}$ (Table 2). The highest $\mathrm{NH}_{4}{ }^{+}-\mathrm{N}$ content was in $\mathrm{NPK}+\mathrm{C}$ and the lowest in CT. In addition, significant differences in soil $\mathrm{NO}_{3}{ }^{-}-\mathrm{N}$ contents were detected among all treatments (Table 2).

\section{Abundance of AOA and AOB in the paddy soil}

The abundance of $\mathrm{AOB}$ and $\mathrm{AOA}$ based on amoA genes were detected using real-time PCR. Some variations in the AOA abundance were observed in different fertilization treatments (Fig. 1). The archaeal amoA gene copy numbers varied from $8.31 \times 10^{7}$ to $2.12 \times 10^{8}$ copies per gram dry soil (Fig. 1). The AOA population size in $\mathrm{NPK}+\mathrm{C}$ was higher than that in CT. No significant differences in the AOB abundance were observed among the treatments (Fig. 1). The average bacterial amo $A$ gene copy numbers was $1.90 \times$ $10^{5}$ copies per gram dry soil in the paddy soil (Fig. 1). The ratios of $\mathrm{AOA}$ to $\mathrm{AOB}$ amoA gene copy numbers ranged from 417 to 2,383 in all treatments, indicating that the AOA abundance among the treatments was significantly higher than that of AOB (paired-sample $t$ test, $P<0.05$ ). In addition, the correlation analysis indicated that the AOA abundance had a positive correlation with soil total N $(r=$
$0.519, n=18, P<0.05)$, organic matter $(r=0.486, n=18$, $P<0.05)$, and $\mathrm{NH}_{4}{ }^{+}-\mathrm{N}$ content $(r=0.576, n=18, P<0.05)$, while the AOB abundance had a positive correlation with soil $\mathrm{pH}(r=0.521, n=18, P<0.05)$ and $\mathrm{NH}_{4}{ }^{+}-\mathrm{N}$ content $(r=0.514, n=18, P<0.05)$.

Community structure and phylogeny of AOA in the paddy soil

The AOA community structures from different fertilization treatments in the paddy soil were determined by T-RFLP. Four main T-RFs $(330,371,422$, and 444 bp) were present in all treatments, but they showed significant differences $(P<0.05)$ in their relative abundance among fertilization treatments (Fig. 2). The T-RF of $371 \mathrm{bp}$ was detected with the highest relative abundance $(35 \%)$ in $\mathrm{NPK}+\mathrm{C}$ treatment, while in other treatments, 444-bp T-RF was the dominating peak (31-40\%). The T-RF of $330 \mathrm{bp}$ was the lowest relative abundance in NPK and NPK $+\mathrm{C}$ treatments, while in other treatments, 330- and 371-bp T-RFs were both the lowest relative abundance. These community shifts were further investigated by PCA (Fig. 3). The first PCA axis, which is related to the main compositional variation, separated the communities of the different treatments. The main variation was mainly caused by changes in the relative abundance of the 371- and 444-bp T-RFs.

In order to identify the individual T-RF, clone libraries of archaeal amoA gene were constructed from CT, NK, and $\mathrm{NPK}+\mathrm{C}$ treatments. Randomly selected clones were sequenced and these clones (with 50 clones for CT, 50 clones for $\mathrm{NK}$, and 47 clones for $\mathrm{NPK}+\mathrm{C}$ ) characterized with T-RFLP analysis. The sequence data are shown in a phylogenetic tree, also indicating the length of the T-RF obtained for individual clones (Fig. 4). All AOA sequences fell into two main clusters: $80 \%$ are in cluster $\mathrm{A}$ and others are in soil/sediment. The clones with T-RFs of 371 and $422 \mathrm{bp}$ were only assigned to cluster A, while those with T-RFs of 330 and 444 bp were detected in the two clusters.

Table 2 Basic properties of the paddy soil under different fertilization treatments

\begin{tabular}{lcccccccc}
\hline Treatment $^{\mathrm{a}}$ & $\begin{array}{l}\text { Sand } \\
(\%)\end{array}$ & $\begin{array}{l}\text { Silt } \\
(\%)\end{array}$ & $\begin{array}{l}\text { Clay } \\
(\%)\end{array}$ & $\mathrm{pH}\left(\mathrm{H}_{2} \mathrm{O}\right)$ & $\begin{array}{l}\text { Total nitrogen } \\
\left(\mathrm{mg} \mathrm{kg}^{-1}\right)\end{array}$ & $\begin{array}{l}\text { Organic matter } \\
\left(\mathrm{g} \mathrm{kg}^{-1}\right)\end{array}$ & $\begin{array}{l}\mathrm{NH}_{4}^{+}-\mathrm{N}^{-1} \\
\left(\mathrm{mg} \mathrm{kg}^{-1}\right)\end{array}$ \\
\hline $\mathrm{CT}$ & 11 & 65 & 24 & $5.39 \pm 0.08 \mathrm{~b}$ & $180 \pm 10 \mathrm{a}$ & $29.2 \pm 1.3 \mathrm{a}$ & $27.1 \pm 1.3 \mathrm{a}$ & $\begin{array}{l}\mathrm{NO}_{3}^{-}-\mathrm{N}^{-1} \\
\left(\mathrm{mg} \mathrm{kg}^{-1}\right)\end{array}$ \\
$\mathrm{N}$ & 11 & 66 & 23 & $5.26 \pm 0.10 \mathrm{ab}$ & $188 \pm 23 \mathrm{a}$ & $29.8 \pm 4.1 \mathrm{a}$ & $53.5 \pm 3.6 \mathrm{~b}$ & $0.55 \pm 0.04 \mathrm{a}$ \\
$\mathrm{NK}$ & 11 & 64 & 25 & $5.34 \pm 0.04 \mathrm{~b}$ & $190 \pm 29 \mathrm{a}$ & $30.4 \pm 5.4 \mathrm{a}$ & $55.8 \pm 6.6 \mathrm{~b}$ & $0.65 \pm 0.09 \mathrm{ab}$ \\
$\mathrm{NP}$ & 13 & 65 & 24 & $5.23 \pm 0.03 \mathrm{ab}$ & $198 \pm 39 \mathrm{a}$ & $32.0 \pm 6.3 \mathrm{a}$ & $46.3 \pm 5.5 \mathrm{~b}$ & $0.76 \pm 0.01 \mathrm{bc}$ \\
$\mathrm{NPK}$ & 12 & 70 & 18 & $5.09 \pm 0.05 \mathrm{a}$ & $200 \pm 28 \mathrm{a}$ & $32.1 \pm 4.7 \mathrm{a}$ & $46.6 \pm 1.5 \mathrm{~b}$ & $0.80 \pm 0.04 \mathrm{c}$ \\
$\mathrm{NPK}+\mathrm{C}$ & 12 & 69 & 19 & $5.30 \pm 0.14 \mathrm{~b}$ & $267 \pm 04 \mathrm{~b}$ & $41.6 \pm 0.8 \mathrm{~b}$ & $85.9 \pm 8.12 \mathrm{c}$ & $0.93 \pm 0.11 \mathrm{~d}$ \\
\hline
\end{tabular}

${ }^{a}$ Treatment: control without fertilizers $(\mathrm{CT})$, fertilizer N (N), fertilizers NK (NK), fertilizers NP (NP), fertilizers NPK (NPK), fertilizers NPK plus recycled crop residues $(\mathrm{NPK}+\mathrm{C})$. Values are mean or mean \pm standard deviation $(n=3)$. Values within the same column followed by the different letters indicate significant difference $(P<0.05)$ 


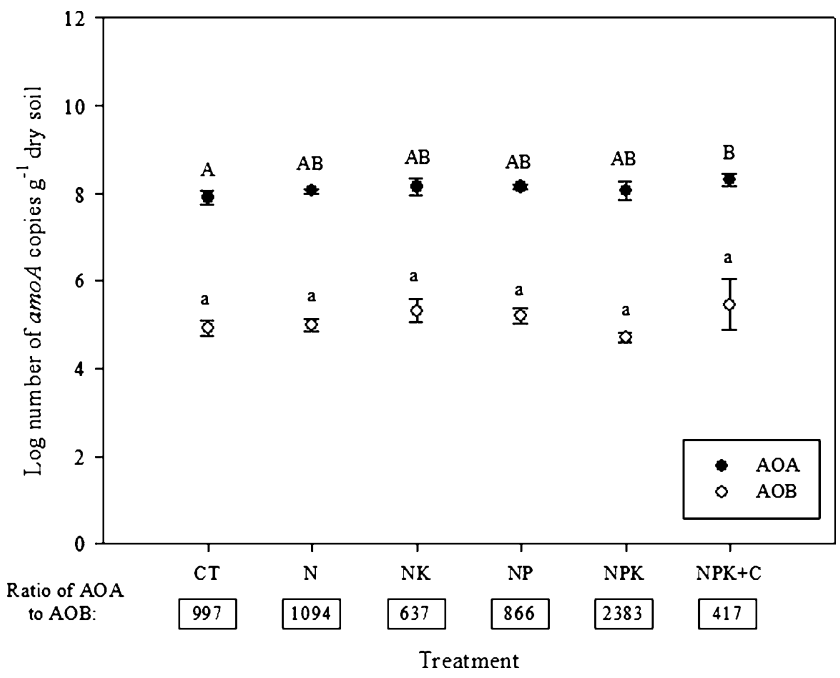

Fig. 1 Abundance of AOA and AOB based on amoA genes in the paddy soil under different fertilization treatments. Different letters on the points indicate significant difference $(P<0.05)$. Ratios of AOA to AOB amoA gene copy numbers are shown at the bottom of each treatment. $C T$ control without fertilizers, $N$ fertilizer $\mathrm{N}, N K$ fertilizers NK, $N P$ fertilizers NP, $N P K$ fertilizers NPK, $N P K+C$ fertilizers NPK plus recycled crop residues

Community structure and phylogeny of AOB in the paddy soil

Using T-RFLP to investigate the AOB community structures, only one dominant T-RF of $109 \mathrm{bp}$ was detected in all treatments. Three AOB clone libraries with 127 clones from $\mathrm{CT}$, NK, and $\mathrm{NPK}+\mathrm{C}$ treatments were screened for the TRF. Phylogenetic analysis revealed that most sequences

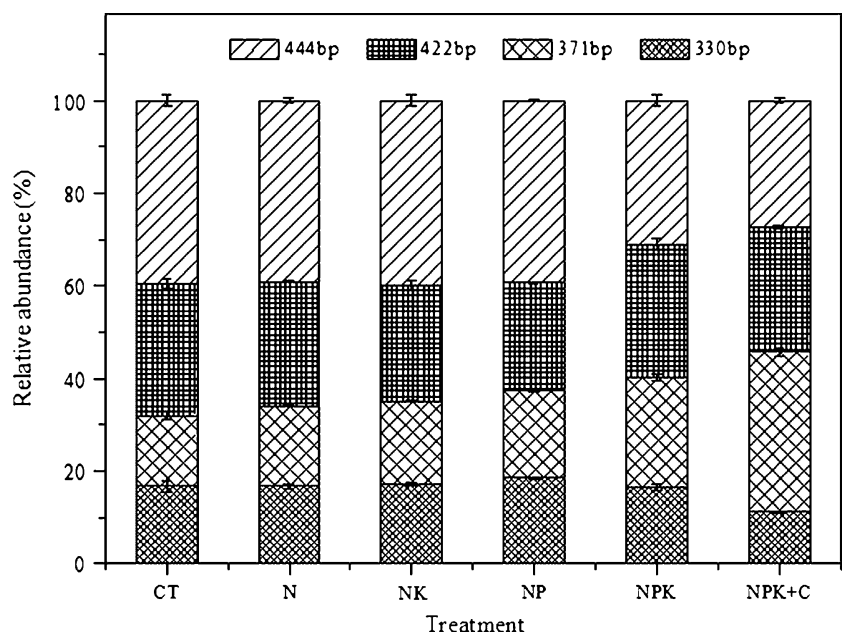

Fig. 2 Relative abundance of T-RFs for AOA in the paddy soil under different fertilization treatments. Bars represent the mean of three replicates with standard deviation. $C T$ control without fertilizers, $N$ fertilizer N, $N K$ fertilizers NK, $N P$ fertilizers NP, $N P K$ fertilizers NPK, $N P K+C$ fertilizers NPK plus recycled crop residues

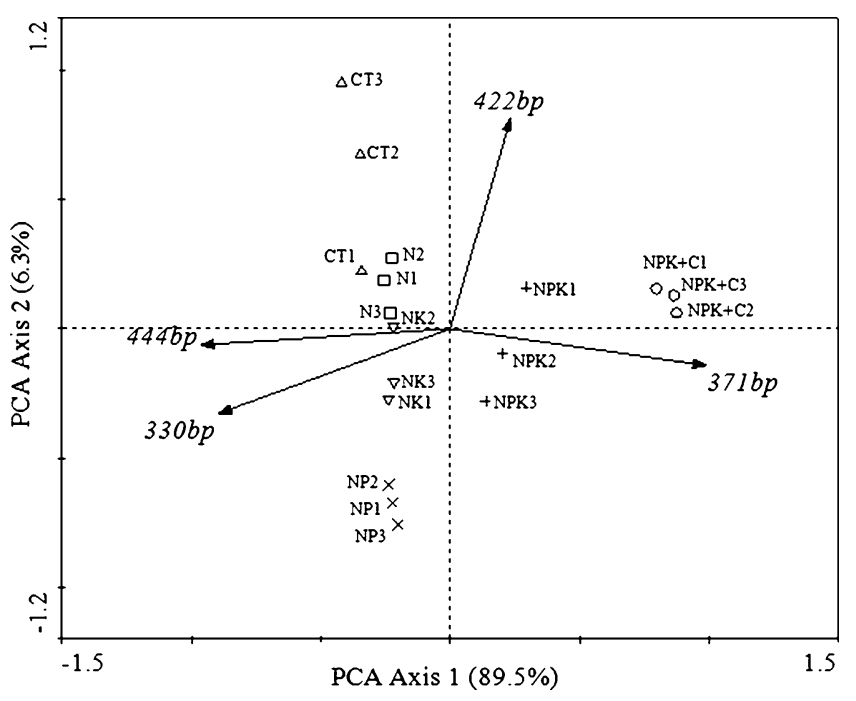

Fig. 3 Principle component analysis $(P C A)$ of T-RFLP profiles using archaeal amo $A$ gene T-RF relative abundance data obtained from the different fertilization treatments in the paddy soil. The percentages indicate the proportions of variation explained by the first and second ordination axes. Symbols indicate different treatments: CT treatment (up-triangle), $\mathrm{N}$ treatment (square), $\mathrm{NK}$ treatment (down-triangle), $\mathrm{NP}$ treatment (X mark), NPK treatment (cross), NPK $+\mathrm{C}$ treatment (circle). The numbers in the labels denote three replicates of each treatment. Arrows indicate the distribution of T-RFs. $C T$ control without fertilizers, $N$ fertilizer $\mathrm{N}, N K$ fertilizers $\mathrm{NK}, N P$ fertilizers $\mathrm{NP}, N P K$ fertilizers NPK, $N P K+C$ fertilizers NPK plus recycled crop residues

with T-RF of 109 bp belonged to Nitrosospira amoA cluster 12 (Fig. 5). A few remaining sequences with the restriction site that was not found in the T-RFLP analysis were affiliated with Nitrosospira amoA cluster 11 (Fig. 5).

\section{Discussion}

Effects of different fertilization treatments on soil AOA and $\mathrm{AOB}$ abundance

Although flooding paddy soil is predominantly anaerobic, we detected large numbers of AOA $\left(8.31 \times 10^{7}-2.12 \times 10^{8}\right.$ copies per gram dry soil) in this acid paddy soil, similar to some upland soils (Shen et al. 2008; Ying et al. 2010). Previous studies also found high abundance of AOA in low-oxygen environments (Park et al. 2006; Lam et al. 2007; Santoro et al. 2008). In addition, long-term fertilizer application seemed to stimulate the AOA growth, especially the NPK + C. A previous study also found that the AOA population size changed greatly in respond to the different fertilization treatments (He et al. 2007). In that study, the changes of soil $\mathrm{pH}$ caused by long-term mineral fertilization played a main role in affecting AOA population size. However, in this study, the fertilizer itself as a substrate supply for AOA could play a more important role than the 
Fig. 4 Neighbor-joining phylogenetic tree of archaeal amoA sequences retrieved from $\mathrm{CT}$, $\mathrm{NK}$, and $\mathrm{NPK}+\mathrm{C}$ fertilization treatments of the paddy soil. Sequences from this study are shown in bold. Between brackets Sequence number belonging to the OTU in each treatment and the corresponding T-RF size. Bootstrap values $(>50)$ are indicated at branch points. The scale bar represents $5 \%$ estimated sequence divergence. $C T$ control without fertilizers, $N K$ fertilizers NK, $N P K+C$ fertilizers NPK plus recycled crop residues

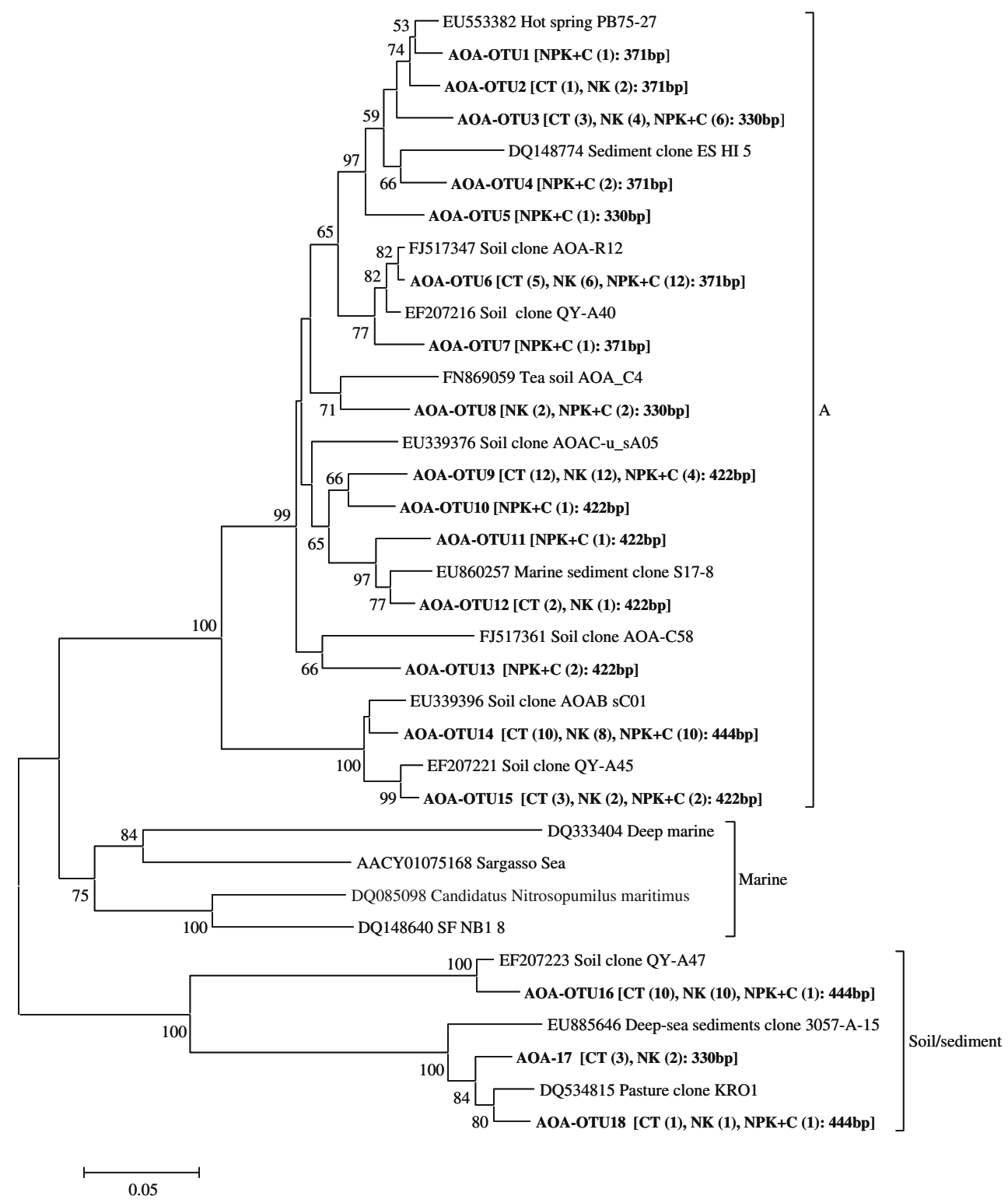

soil $\mathrm{pH}$. Statistical analyses showed that the AOA abundance has a positive correlation with soil total $\mathrm{N}(r=0.519$, $n=18, P<0.05)$, organic matter $(r=0.486, n=18, P<0.05)$, and $\mathrm{NH}_{4}{ }^{+}-\mathrm{N}$ content $(r=0.576, n=18, P<0.05)$, further confirming the major effect of the fertilizer itself as a substrate.

In our study, the bacterial amo $A$ copy numbers were on average $1.90 \times 10^{5}$ copies per gram dry soil in different fertilization treatments, similar to a recent report which found that the bacterial amoA gene copy numbers ranged from $1.0 \times 10^{5}$ to $9.3 \times 10^{5}$ copies per gram dry soil in the upland and flooded bulk soils of a Japanese rice paddy field over 2 years (Fujii et al. 2010). However, compared with some results of upland soils ( $\mathrm{He}$ et al. 2007), the AOB abundance was lower, indicating that aerobic conditions may be an important factor determining the AOB popula- tion size in soil (Chu et al. 2010). Though the correlation analysis showed the AOB abundance to have a positive correlation with soil $\mathrm{pH}(r=0.521, n=18, P<0.05)$ and $\mathrm{NH}_{4}{ }^{+}-\mathrm{N}$ content $(r=0.514, n=18, P<0.05)$, no significant differences in the AOB abundance were detected among the different fertilization treatments. This indicates that the $\mathrm{pH}$ and the substrate $\left(\mathrm{NH}_{4}{ }^{+}-\mathrm{N}\right)$ content could have some influence on the AOB abundance. However, as the low $\mathrm{pH}$ values and oxygen environment in all treatments were not suitable for the AOB growth (Prosser 1989), the effects of fertilizer application were not significant. In addition, compared with the AOA copy numbers, the AOB were also much lower, which were consistent with many studies of agricultural soils (Leininger et al. 2006; He et al. 2007; Shen et al. 2008). Therefore, these results may imply that the AOB growth was inhibited. 
Fig. 5 Neighbor-joining phylogenetic tree of bacterial amoA sequences retrieved from $\mathrm{CT}$, $\mathrm{NK}$, and $\mathrm{NPK}+\mathrm{C}$ fertilization treatments of the paddy soil. Sequences from this study are shown in bold. Between brackets Sequence number belonging to the OTU in each treatment and the corresponding T-RF size. Bootstrap values $(>50)$ are indicated at branch points. The scale bar represents $5 \%$ estimated sequence divergence. $C T$ control without fertilizers, $N K$ fertilizers $\mathrm{NK}, \mathrm{NPK}+\mathrm{C}$ fertilizers NPK plus recycled crop residues

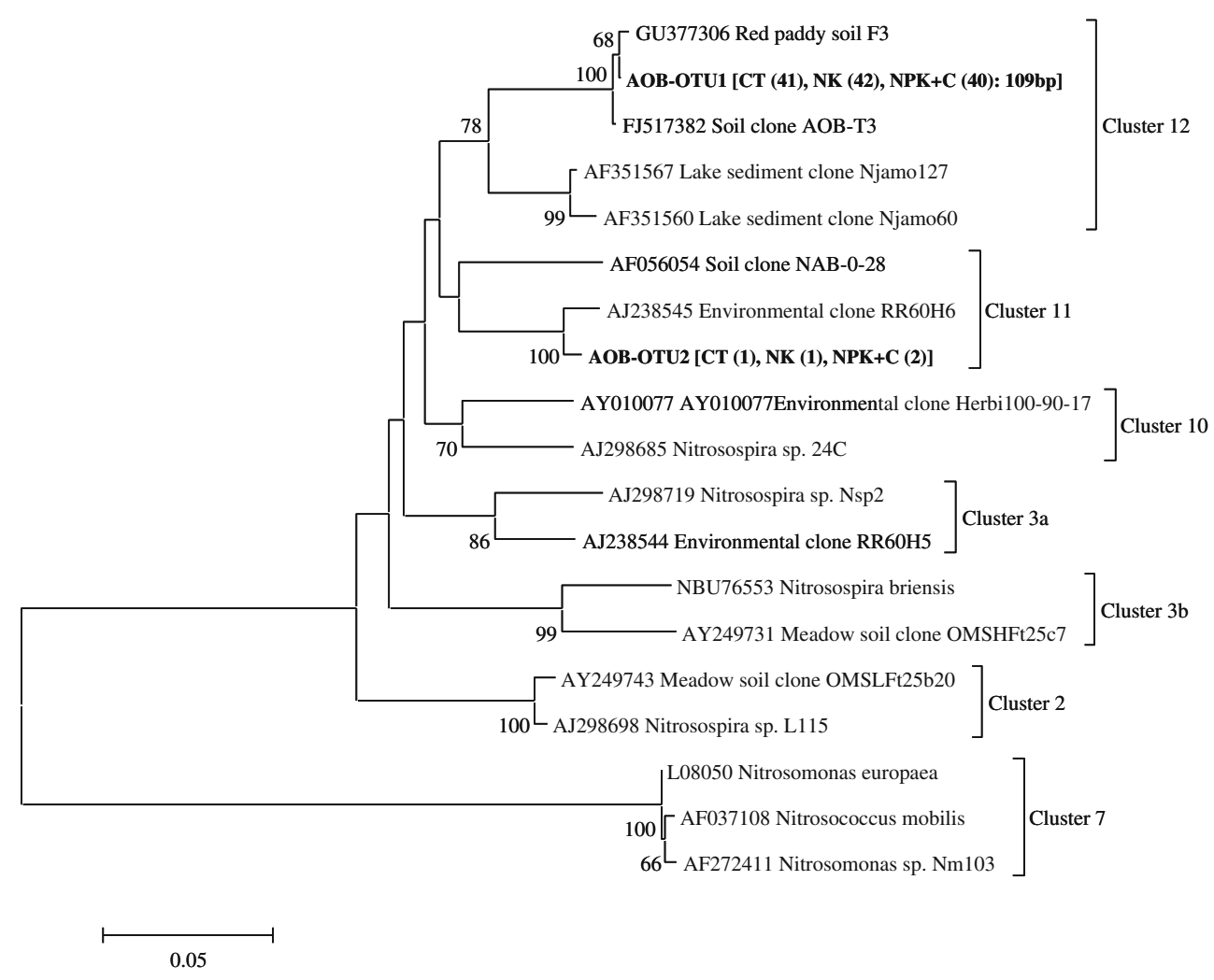

Effects of different fertilization treatments on soil AOA and AOB community structure

By using T-RFLP analysis and PCA, we found that there were some changes in AOA community composition responding to different fertilization treatments in the paddy soil, while few differences were detected in the AOB community. These results were consistent with those of $\mathrm{He}$ et al. (2007) in upland of acid red soil. Ying et al. (2010) also found the shift of AOA to cultivation in acid red soils. Thus, it could be hypothesized that AOA were more sensitive than AOB in acid red soils, irrespective of paddy soil and upland soil.

Phylogeny of AOA and AOB in the paddy soil

The sequences of AOA obtained from this study were associated with two distinct clusters (cluster A and cluster soil/sediment), and the majority of sequences were placed within cluster A. In a previous study, cluster A was defined as sediment and soil $\mathrm{V}$, which was distinct from soil and marine clusters (Nicol et al. 2008). It was also interesting to note that the sequences (this study and references) which were placed in cluster A were all cloned from a low $\mathrm{pH}$ environment. Other sequences in our study fell into soil/sediment cluster, which were closely related to the sequences commonly obtained from soil and marine sediments.
Phylogenetic analyses of AOB identified that Nitrosospira-like species dominated in this study, as already shown in paddy soils (Bowatte et al. 2006; Chen et al. 2008; Chu et al. 2010). It has been reported that the AOB in the Japanese paddy field was dominated by Nitrosospira amoA cluster 1 (Bowatte et al. 2006; Chu et al. 2010). Other researches also detected Nitrosospira amoA cluster 3 in the paddy soils (Chen et al. 2008; Wang et al. 2009). However, in this study, most $\mathrm{AOB}$ sequences contained T-RF of $109 \mathrm{bp}$, which belongs to Nitrosospira amoA cluster 12, and few sequences grouped in Nitrosospira amoA cluster 11, which were not commonly reported in previous reports. Although Nitrosospira amoA clusters 1, 2, 3 , and 4 have been identified in acidic forest soils or fertilized upland soils (Laverman et al. 2001; Mintie et al. 2003; Compton et al. 2004; Nugroho et al. 2005; He et al. 2007; Boyle-Yarwood et al. 2008), we did not detect those clusters, suggesting that acid red paddy soil may have the unique amo $A$ lineage.

\section{Conclusions}

In conclusion, this study found that the AOA abundance and community composition had some changes among the fertilization treatments in the paddy soil, but few differences were observed in the $\mathrm{AOB}$, suggesting that $\mathrm{AOA}$ 
were more sensitive to different fertilization treatments in the acid red paddy soil than AOB.

Acknowledgments This work was supported by the Natural Science Foundation of China (41090281, 50921064, 41025004) and the Chinese Academy of Sciences (KSCX2-YW-G-072, International Partnership Program for Creative Research Teams of "Ecosystem Processes and Services").

\section{References}

Bowatte S, Asakawa S, Okada M, Kobayashi K, Kimura M (2007) Effect of elevated atmospheric $\mathrm{CO}_{2}$ concentration on ammonia oxidizing bacteria communities inhabiting in rice roots. Soil Sci Plant Nutr 53:32-39

Bowatte S, Jia Z, Ishihara R, Nakajima Y, Asakawa S, Kimura M (2006) Molecular analysis of the ammonia oxidizing bacterial community in the surface soil layer of Japanese paddy field. Soil Sci Plant Nutr 52:427-431

Boyle-Yarwood SA, Bottomley PJ, Myrold DD (2008) Community composition of ammonia-oxidizing bacteria and archaea in soils under stands of red alder and Douglas fir in Oregon. Environ Microbiol 10:2956-2965

Briones AM, Okabe S, Umemiya Y, Ramsing N-B, Reichardt W, Okuyama H (2002) Influence of different cultivars on populations of ammonia-oxidizing bacteria in the root environment of rice. Appl Environ Microbiol 68:3067-3075

Chen XP, Zhu YG, Xia Y, Shen JP, He JZ (2008) Ammonia-oxidizing archaea: important players in paddy rhizosphere soil? Environ Microbiol 10:1978-1987

Chu HY, Morimoto S, Fujii T, Yagi K, Nishimura S (2010) Soil ammonia-oxidizing bacterial communities in paddy rice fields as affected by upland conversion history. Soil Sci Soc Am J 73:2026-2031

Compton JE, Watrud LS, Porteous LA, Degrood S (2004) Response of soil microbial biomass and community composition to chronic nitrogen additions at Harvard Forest. For Ecol Manage 196:143158

Conrad R, Rothfuss F (1991) Methane oxidation in the soil surface layer of a flooded rice field and the effect of ammonium. Biol Fertil Soils 12:28-32

Di HJ, Cameron KC, Shen JP, Winefield CS, O'Callaghan M, Bowatte S, He JZ (2009) Nitrification driven by bacteria and not archaea in nitrogen-rich grassland soils. Nat Geosci 2:621-624

Erguder TH, Boon N, Wittebolle L, Marzorati M, Verstraete W (2009) Environmental factors shaping the ecological niches of ammoniaoxidizing archaea. FEMS Microbiol Rev 33:855-869

Francis CA, Roberts KJ, Beman JM, Santoro AE, Oakley BB (2005) Ubiquity and diversity of ammonia-oxidizing archaea in water columns and sediments of the ocean. Proc Natl Acad Sci USA 102:14683-14688

Fujii C, Nakagawa T, Onodera Y, Matsutani N, Sasada K, Takahashi R, Tokuyama T (2010) Succession and community composition of ammonia-oxidizing archaea and bacteria in bulk soil of a Japanese paddy field. Soil Sci Plant Nutr $56: 212-219$

He JZ, Shen JP, Zhang LM, Zhu YG, Zheng YM, Xu MG, Di HJ (2007) Quantitative analyses of the abundance and composition of ammonia-oxidizing bacteria and ammonia-oxidizing archaea of a Chinese upland red soil under long-term fertilization practices. Environ Microbiol 9:2364-2374

Jia ZJ, Conrad R (2009) Bacteria rather than Archaea dominate microbial ammonia oxidation in an agricultural soil. Environ Microbiol 11:1658-1671
Kettler TA, Doran JW, Gilbert TL (2001) Simplified method for soil particle-size determination to accompany soil-quality analyses. Soil Sci Soc Am J 65:849-852

Könneke M, Bernhard AE, de la Torre JR, Walker CB, Waterbury JB, Stahl DA (2005) Isolation of an autotrophic ammonia-oxidizing marine archaeon. Nature 437:543-546

Lam P, Jensen MM, Lavik G, McGinnis DF, Müller B, Schubert CJ, Amann R, Thamdrup B, Kuypers MMM (2007) Linking crenarchaeal and bacterial nitrification to anammox in the Black Sea. Proc Natl Acad Sci USA 104:7104-7109

Laverman AM, Speksnijder AGCL, Braster M, Kowalchuk GA, Verhoef HA, van Verseveld HW (2001) Spatiotemporal stability of an ammonia-oxidizing community in a nitrogen-saturated forest soil. Microb Ecol 42:35-45

Leininger S, Urich T, Schloter M, Schwark L, Qi J, Nicol GW, Prosser JI, Schuster SC, Schleper C (2006) Archaea predominate among ammonia-oxidizing prokaryotes in soils. Nature 442:806-809

Mintie AT, Heichen RS, Cromack K, Myrold DD, Bottomley PJ (2003) Ammonia-oxidizing bacteria along meadow-to-forest transects in the Oregon Cascade Mountains. Appl Environ Microbiol 69:3129-3136

Nicol GW, Leininger S, Schleper C, Prosser JI (2008) The influence of soil $\mathrm{pH}$ on the diversity, abundance and transcriptional activity of ammonia oxidizing archaea and bacteria. Environ Microbiol 10:2966-2978

Nicolaisen MH, Risgaard-Petersen N, Revsbech NP, Reichardt W, Ramsing NB (2004) Nitrification-denitrification dynamics and community structure of ammonia oxidizing bacteria in a high yield irrigated Philippine rice field. FEMS Microbiol Ecol 49:359-369

Nugroho RA, Röling WFM, Laverman AM, Zoomer HR, Verhoef HA (2005) Presence of Nitrosospira cluster 2 bacteria corresponds to $\mathrm{N}$ transformation rates in nine acid Scots pine forest soils. FEMS Microbiol Ecol 53:473-481

Offre P, Prosser JI, Nicol GW (2009) Growth of ammonia-oxidizing archaea in soil microcosms is inhibited by acetylene. FEMS Microbiol Ecol 70:99-108

Park H-D, Wells GF, Bae H, Criddle CS, Francis CA (2006) Occurrence of ammonia-oxidizing archaea in wastewater treatment plant bioreactors. Appl Environ Microbiol 72:5643-5647

Prosser JI (1989) Autotrophic nitrification in bacteria. Adv Microb Physiol 30:125-181

Purkhold U, Pommerening-Röser A, Juretschko S, Schmid MC, Koops H-P, Wagner M (2000) Phylogeny of all recognized species of ammonia oxidizers based on comparative 16S rRNA and $a m o A$ sequence analysis: implications for molecular diversity surveys. Appl Environ Microbiol 66:5368-5382

Revsbech NP, Pedersen O, Reichardt W, Briones A (1999) Microsensor analysis of oxygen and $\mathrm{pH}$ in the rice rhizosphere under field and laboratory conditions. Biol Fertil Soils 29:379-385

Rotthauwe JH, Witzel KP, Liesack W (1997) The ammonia monooxygenase structural gene amo $A$ as a functional marker: molecular fine-scale analysis of natural ammonia-oxidizing populations. Appl Environ Microbiol 63:4704-4712

Santoro AE, Francis CA, de Sieyes NR, Boehm AB (2008) Shifts in the relative abundance of ammonia-oxidizing bacteria and archaea across physicochemical gradients in a subterranean estuary. Environ Microbiol 10:1068-1079

Schauss K, Focks A, Leininger S, Kotzerke A, Heuer H, Thiele-Bruhn S, Sharma S, Wilke BM, Matthies M, Smalla K, Munch JC, Amelung W, Kaupenjohann M, Schloter M, Schleper C (2009) Dynamics and functional relevance of ammonia-oxidizing archaea in two agricultural soils. Environ Microbiol 11:446-456

Shen JP, Zhang LM, Zhu YG, Zhang JB, He JZ (2008) Abundance and composition of ammonia-oxidizing bacteria and ammonia- 
oxidizing archaea communities of an alkaline sandy loam. Environ Microbiol 10:1601-1611

Tamura K, Dudley J, Nei M, Kumar S (2007) MEGA4: Molecular Evolutionary Genetics Analysis (MEGA) software version 4.0. Mol Biol Evol 24:1596-1599

Treusch AH, Leininger S, Kletzin A, Schuster SC, Klenk HP, Schleper C (2005) Novel genes for nitrite reductase and Amo-related proteins indicate a role of uncultivated mesophilic crenarchaeota in nitrogen cycling. Environ Microbiol 7:1985-1995

Valentine DL (2007) Adaptations to energy stress dictate the ecology and evolution of the Archaea. Nat Rev Microbiol 5:316-323

Venter JC, Remington K, Heidelberg JF, Halpern AL, Rusch D, Eisen JA, Wu DY, Paulsen I, Nelson KE, Nelson W, Fouts DE, Levy S, Knap AH, Lomas MW, Nealson K, White O, Peterson J, Hoffman J, Parsons R, Baden-Tillson H, Pfannkoch C, Rogers YH, Smith HO (2004) Environmental genome shotgun sequencing of the Sargasso Sea. Science 304:66-74

Wang YN, Ke XB, Wu LQ, Lu YH (2009) Community composition of ammonia-oxidizing bacteria and archaea in rice field soil as affected by nitrogen fertilization. Syst Appl Microbiol 32:27-36

Wuchter C, Abbas B, Coolen MJL, Herfort L, Van Bleijswijk J, Timmers P, Strous M, Teira E, Herndl GJ, Middelburg JJ, Schouten S, Damste JSS (2006) Archaeal nitrification in the ocean. Proc Natl Acad Sci USA 103:12317-12322

Ying JY, Zhang LM, He JZ (2010) Putative ammonia-oxidizing bacteria and archaea in an acidic red soil with different land utilization patterns. Environ Microbiol Rep 2:304-312

Zhang LM, Offre PR, He JZ, Verhamme DT, Nicol GW, Prosser JI (2010) Autotrophic ammonia oxidation by soil thaumarchaea. Proc Natl Acad Sci USA 107:17240-17245

Zhang LM, Wang M, Prosser JI, Zheng YM, He JZ (2009) Altitude ammonia-oxidizing bacteria and archaea in soils of Mount Everest. FEMS Microbiol Ecol 70:208-217

Zheng Y, Zhang LM, Zheng YM, Di HJ, He JZ (2008) Abundance and community composition of methanotrophs in a Chinese paddy soil under long-term fertilization practices. J Soils Sediment 8:406-414 